\title{
Retributivism and Public Opinion: On the Context Sensitivity of Desert
}

\author{
Göran Duus-Otterström ${ }^{1,2}$
}

(C) The Author(s) 2017. This article is an open access publication

\begin{abstract}
Retributivism may seem wholly uninterested in the fit between penal policy and public opinion, but on one rendition of the theory, here called 'popular retributivism,' deserved punishments are constituted by the penal conventions of the community. This paper makes two claims against this view. First, the intuitive appeal of popular retributivism is undermined once we distinguish between context sensitivity and convention sensitivity about desert. Retributivism in general can freely accept context sensitivity without being committed to the stronger notion of convention sensitivity. Second, it is not obviously a merit of popular retributivism that it admits a gradual lowering of punishments by softening public opinion. Retributivists have reason to be skeptical of softening public opinion if it comes at the price of undermining the extent to which offenders are thought to deserve censure. In sum, in this paper, I argue that there are ways of making retributivism sensitive to public opinion without arriving at the conclusion that popular penal conventions should govern retributive justice itself.
\end{abstract}

Keywords Desert · Proportionality $\cdot$ Punishment $\cdot$ Retributivism $\cdot$ Sentencing

Göran Duus-Otterström

goran.duus-otterstrom@pol.gu.se

1 Department of Political Science, University of Gothenburg, Box 711, 40530 Gothenburg, Sweden

2 Institute for Futures Studies, Stockholm, Sweden 


\section{Introduction}

Legal and political philosophers are taking an increasing interest in whether criminal policy should be congruent with public opinion, especially in matters of sentencing (Ryberg and Roberts 2014). ${ }^{1}$ While there are good consequentialist reasons for such 'popular punishment' - such as that the criminal justice system needs popular support if it is to be effective in preventing crime (Robinson 2013) - there seems to be no retributive reasons to care about congruence with penal public opinion. ${ }^{2}$ Consider positive retributivism. Positive retributivism is the view that every (appropriately criminalized) offense deserves a particular punishment and that it is permissible, and generally desirable, for the state to mete out deserved punishments. Since there is no necessary relationship between what an offender deserves and what the public thinks he or she deserves, this view appears entirely uninterested in the fit between public opinion and penal policy. If the public desires harsher (or milder) punishments than an offender truly deserves, the right response isn't to increase (or decrease) the amount of punishment, but to educate the public so that it comes to see what retributive justice requires. A similar thing could be said about negative retributivism and its idea that the deserved punishment must not be exceeded.

But things are not quite so straightforward. The retributivist assertion that criminal offenses of a particular seriousness deserve punishments of a particular severity is just an empty formula. It needs to be injected with values for criminal seriousness and penal severity, as well as with some method for pairing the two. This potentially leaves the door wide open for public opinion and popular input. Consider the following two approaches:

Objective retributivism: There is a fact to the matter concerning what punishment a crime deserves, such that what any amount of people believes to be the deserved punishment isn't necessarily what is in fact the deserved punishment.

Popular retributivism: Which punishment a crime deserves is determined by what the members of the relevant community think is the deserved punishment, such that when a sufficiently large percentage of members think that something is the deserved punishment, then it $i s$ the deserved punishment.

Objective and popular retributivism are both expressions of what I call, in Sect. 2, 'absolute cardinal proportionality' in punishment. They both express the familiar retributive belief that crimes deserve to be met with punitive responses of a particular severity. But they are quite different and suggest contrasting images of retributive justicethe former makes it a business for expert sentencing commissions or the like; the latter makes it a matter of popular input and participatory democracy. If pressed to choose between them, starkly formulated as they are, I suspect most retributivists would side with objective retributivism. But it is interesting to note that there is a tendency in the literature to defend views that, at least on the face of it, are more reminiscent of popular

\footnotetext{
1 Sensitivity to public opinion can take different forms and vary in strength, but in general it is measured in terms of policy congruence, which is the fit between policies and the policy preferences of citizens (Andeweg 2011). Policy congruence is related to the concept of policy responsiveness, which is when changes in public opinion are reflected in policy (Stimson et al. 1995; Wlezien 1995). In recent years, scholars have started to disaggregate public opinion in order to get a more nuanced picture of policy congruence; see, e.g., Gilens (2012).

2 For democratic arguments for popular punishment, see Dzur (2012) and Bennett (2014).
} 
retributivism. I am thinking here of communicative versions of retributivism. ${ }^{3}$ Such versions are not tied to popular retributivism as a matter of logical necessity. Indeed, I suspect many communicative retributivists would want to reject this view. ${ }^{4}$ But communicative retributivism is nevertheless especially open or vulnerable to a 'popular' reading, because it holds that punishment is justified in virtue of conveying the community's censure of the offender. If the state is to communicate censure on behalf of a community, it is important that it punishes in a way that at least broadly corresponds with the values and beliefs of the members of that community. ${ }^{5}$ A state that, for example, inflicted minor punishments on what the public considered serious criminal wrongs wouldn't succeed in censuring on the public's behalf.

My overall aim in this paper is to offer an analysis of popular retributivism, which I think is an important view not least because it sheds light on neglected issues in retributivist thought related to the source and nature of desert claims. Popular retributivism may seem innocuous, democratic even, but it has a radical implication. In leaving the standards for deserved punishment to the relevant political community to decide, it entails that any crime could in principle be proportionally punished by any punishment. In this paper, I will discuss two aspects of this implication, one that I think will worry many people and one that is probably deemed more attractive. My hope is that this will illuminate not only the relationship between retributivism and public opinion, but also raise new questions about desert and proportionality within retributivist thought.

The worrying aspect of popular retributivism is that it seems to make retributivists unable to criticize penal policy when penal policy is line with popular conventions. It simply comes with an unmistakable air of relativism, and as with all forms of relativism it raises questions about the possibility of external, as opposed to internal, moral criticism. ${ }^{6}$ Yet, despite this worry, some may feel forced to bite the bullet here because the alternative seems wedded to an implausible brand of context-free moral realism. My first specific aim in this paper is to discuss, and largely disarm, this thought. This will not involve extensive discussion of meta-ethical issues, let alone taking a stand on them. For the purposes of this paper, I will remain agnostic as to which meta-ethical view we should adopt. Instead, I will point out, in Sect. 3, that it is crucial that we make a distinction between context sensitivity and convention sensitivity. Context sensitivity is the idea that criminal and penal harm are affected by the surrounding political, social, and cultural circumstances. Convention sensitivity is the stronger idea that popular conventions determine the requirements of retributive justice themselves. I will suggest that much of the apparent appeal of popular retributivism stems from the quite uncontroversial idea of context sensitivity. We are free to opt for objective retributivism as long as we deny convention sensitivity.

\footnotetext{
${ }^{3}$ For overviews of communicative (or expressive) versions of retributivism, see Boonin (2008, 172-180), Brooks (2012, 102-122), and Hoskins (2016). For statements of communicative retributivism, see, e.g., von Hirsch and Ashworth (2005), Bennett (2008); and, especially, Duff (2001). It should be noted that a theory like Duff's is not purely retributivist since it is not solely backwards looking, and that it is possible to emphasize the communicative aspects of punishment without being a retributivist at all. But a theory that justifies punishment at least partly in terms of its communicating appropriate censure in my view qualifies as retributivist.

${ }^{4}$ Duff, for example, writes: 'Given an appropriate set of conventions and a shared understanding of those conventions, a term of imprisonment [...] can communicate [...] an authoritative censure or condemnation of the crime for which it is imposed' (2001, 29. Emphasis added).

5 To the best of my knowledge, this argument has been most carefully developed by Matravers (2014). I will return to his argument below.

${ }^{6}$ For internal versus external criticism, see, e.g., Walzer (1987); and Bird (2006, Ch. 1).
} 
Having clarified (and undermined) popular retributivism, I then turn, in Sect. 4, to an aspect of this view that I believe many will find attractive, namely that it would allow retributivists to pursue what I will call 'penal nudging,' that is, gradually reducing the popular standards of desert by choosing ever more lenient punishments. Some penologists have touched on this idea, but it has not been adequately developed in the literature and popular retributivism brings it squarely into view. My second aim is to discuss it in more depth. I will raise some doubts about whether it is possible to nudge penal censure in a more lenient direction, noting that the amount of censure a punishment is understood to communicate may be independent of its amount of hard treatment. My main focus, however, is to assess whether penal nudging would be a good thing according to a retributivist if it would reduce censure. I argue that this is doubtful, because it is problematic if serious crime were less condemned in the future. Popular retributivists cannot capture this intuition since the appropriate amount of censure is also constituted by popular beliefs on their account. Context-sensitive retributivists, however, could argue that it would be bad if the context were to change in such a way that serious crimes are less condemned. This could give them a reason not to engage in penal nudging.

In sum, I argue that there are ways of making retributivism sensitive to public opinion/ popular conventions without arriving at the conclusion that popular conventions should govern retributive justice itself. Moreover, even if we accept that context plays a large role for retributive justice, retributivists have theoretical tools to explain why some contexts are preferable to others.

\section{Popular Retributivism}

Before discussing popular retributivism I will first describe retributivism as a theory of sentencing. Generally put, retributivism states that there is a morally deserved punishment for each crime. It is helpful to think of this punishment as the 'desert peak' at which the offender gets what he or she morally deserves, no more and no less, and where a deviation in either direction represents a loss in terms of establishing desert (Kagan 2012, 72-77). Positive retributivism is the view that offenders ought to get the deserved punishment. ${ }^{7}$ Negative retributivism is the view that no offender should be punished in excess of the deserved punishment. ${ }^{8}$

Retributivism is typically expressed in the language of proportionality. While this is just another way of speaking about morally deserved punishments, it is useful since it allows us to disaggregate the components that go into deserved punishments. Proportionality in punishment requires three things:

1. a ranking of crimes in terms of their seriousness;

2. a ranking of punishments in terms of their severity; and

3. a method for pairing items on the two scales.

It is pretty clear what steps 1 and 2 involve, although completing them will often be difficult in practice (Duff 2001, 135-137). Criminal seriousness is standardly defined as a

\footnotetext{
7 Positive retributivism holds that it is permissible, and normally desirable, to inflict the deserved punishment precisely because it is deserved. For different versions of positive retributivism, see Boonin (2008, Ch. 3). Note that there can be non-retributivist reasons to endorse retributive sentencing (Rachels 1997).

${ }^{8}$ Negative retributivism belongs to mixed views since it holds that desert puts an upper limit on the pursuit of other penal aims (Lippke 2014).
} 
function of the harm, or risk of harm, an offender causes and his or her culpability in doing so. ${ }^{9}$ Penal severity is standardly defined in terms of how far a punishment would set back the interests of a typical person. Ranking crimes and punishments consists in ranking them on these dimensions, either on ordinal or cardinal scales. The difference here is that, whereas an ordinal scale only establishes the rank order of items (e.g., ' $x$ is worse than $y$ '), a cardinal scale also establishes the distance between items (e.g., ' $x$ is twice as bad as $y$ ').

Step 3 is the crucial one as far as proportionality is concerned. This step boils down to a choice between two options, depending on whether we are working with ordinal or cardinal scales. On an ordinal approach, proportionality is when the $n$th worst crime receives the $n$th most severe punishment (Davis 1983). On a cardinal approach, proportionality requires that the spacing between items is respected. For example, if crime $C$ is punished by punishment $P$ and crime $C^{*}$ is twice as serious as $C$, then cardinal proportionality requires that $C^{*}$ receive a punishment twice as severe as $P$. Talk of proportionate punishments as 'desert peaks' is consistent with either of these approaches, but the cardinal approach is a much more natural fit for retributivism.

Cardinal proportionality comes in two versions. Absolute cardinal proportionality obtains when cardinal proportionality is paired with an intuitive absolute fit between crimes and punishments. Relative cardinal proportionality is when cardinal proportionality obtains within a system of punishment, independent of its absolute severity. To illustrate, suppose we are setting up a penal system and are deciding between letting the punishment for $C$ be 12 or 24 months' imprisonment. Whichever option we choose, relative cardinal proportionality will be satisfied so long as $C^{*}$ is punished twice as much as $C$ : if $C$ is punished by 12 months, $C^{*}$ should be punished by 24 months; if $C$ is punished by 24 months, $C^{*}$ should be punished by 48 months. The problem with this relative approach is that proportionality may be satisfied in deeply counterintuitive ways. For example, it may be satisfied by giving $C$ a $\$ 10$ fine and $C^{*}$ a $\$ 20$ fine even though $C$ and $C^{*}$ are, say, assault and armed robbery. If we want to find punishments that are not only correctly calibrated relatively speaking but also fitting in an absolute sense, then we are searching for absolute cardinal proportionality. ${ }^{10}$ The traditional idea of making penal harm commensurate to the criminal harm is the most obvious example of absolute cardinal proportionality, but other approaches are also possible. For example, it could be argued that the penal harm should consist in a particular fraction (e.g., one half) of the criminal harm. Since proportionality is supposed to hold between criminal seriousness and penal severity, and since criminal seriousness is seen as a function of harm and culpability, such approaches must also solve the difficult question of how different types or levels of culpability impact criminal seriousness. A minor harm intentionally caused may be a greater wrong than a major harm negligently caused, and proportionality in punishment would need to track this fact. $^{11}$

Objective retributivism and popular retributivism represent different ways of grounding proportionate sentencing, and in principle they can coexist with any of the conceptions of

\footnotetext{
${ }^{9}$ For a recent paper reporting some misgivings about retributivism and harm, see Tomlin (2014).

${ }^{10}$ Absolute cardinal proportionality is traditionally thought of in terms of 'anchoring' a penal scheme (von Hirsch and Ashworth 2005), but it is important for such proportionality that the anchoring point is fitting and not merely stipulated.

${ }^{11}$ What I say in this section differs from how some prominent penologists put it (Duff 2001, 133-135; von Hirsch and Ashworth 2005, Ch. 9). In their terminology, 'ordinal proportionality' includes spacing requirements, and 'cardinal proportionality' adds the requirement that the punishment must be fitting in an absolute sense. This is a non-standard way of speaking of ordinal and cardinal scales, and one that I think should be abandoned.
} 
proportionality described above. But they are most plausibly thought of as different ways to ground absolute cardinal proportionality. ${ }^{12}$ To illustrate, suppose someone says: 'Imprisonment for four years is the proportionate punishment for armed robbery.' This statement will assume a particular view about the wrongness of armed robbery and the badness of four years' imprisonment, as well as an idea as to how crimes and punishments should be paired in virtue of which four years is the appropriate punishment for armed robbery. According to objective retributivism, there is some theoretical standard that, at least in principle, is able to answer these questions. A historically prominent example here is Immanuel Kant and his argument that the 'law of retribution' makes it possible to 'specify definitely the quality and the quantity of punishment' (Kant 1996, 105-106). According to popular retributivism, however, the relevant standards are instead given by the community in which punishment is practiced. The deserved punishment is constituted by what the members of the community take to be a deserved punishment, in light of their beliefs and values.

It is important to stress that the difference between the two views doesn't lie in moral skepticism. Both agree that there is such a thing as a deserved punishment. Both also agree that, as far as retributive justice goes, deserved punishments should be meted out (or at least not exceeded). The difference instead lies in the nature of desert claims. Objective retributivism holds that desert claims are true or false in virtue of some theoretical standard about which everyone could in principle be ignorant. Popular retributivism argues that desert claims are true or false in virtue of cultural and social conventions. It should be noted that these positions are probably end points on a continuum. There could be intermediate views that blend them in various ways. But they represent the main two approaches to desert for retributivism.

It is clear that popular retributivism makes retributivism a theory of popular punishment by definition. But is it plausible? The theory clearly faces many hard questions about how the relevant 'conventions' should be understood and could be uncovered. It is plausible that the conventions are to be found in the penal beliefs and attitudes of the public; but how are these things to be measured? Are surveys enough or do we need something more refined like deliberative polling or citizen commissions? Moreover, how uniform must the attitudes be? Does it matter who agrees and who disagrees with them or is it simply a numbers game? Finally, does it matter if the attitudes are malleable? Some social scientists argue that public opinion is very sensitive, for example, to the way issues are framed by elites. ${ }^{13}$ They would find the idea of penal policy being congruent or incongruent with any stable popular 'convention' inherently suspect.

These are all very relevant—and possibly insuperable—questions for popular retributivism. ${ }^{14}$ Here I will set them to one side, however, since I am more interested in the view as such than in problems of definition and measurement. I will therefore assume that there is such a thing as reasonably stable and uniform popular conventions about crime and punishment that are able to provide at least a rough blueprint for a scheme of proportionate punishment. My interest is whether retributivists should be popular retributivists in such circumstances.

\footnotetext{
12 Note that the popular standards popular retributivism refers to could operate on the ranking and spacing of the items, too, and not only the way they are paired. I return to this shortly, when I make the distinction between context sensitivity and convention sensitivity about desert.

13 There is a huge political science literature on the nature of public opinion. A modern classic is Zaller (1992). Kuklinksi and Peyton (2007) offer a good overview.

14 Brooks (2012, 106-122) has a good discussion of these questions.
} 
The immediate answer is: it depends. If it turns out that desert claims are constituted by popular conventions, then a retributivist would have to track these conventions. A retributivist is someone who claims that the justification of punishment is centrally tied up with claims about what different offenders deserve. So the real question is: are desert claims constituted by popular conventions?

Several considerations seem to suggest so. Most importantly, desert claims vary considerably between societies and over time. For example, there are manifest differences between what offenders are generally thought to deserve in Scandinavian countries and in the US, not to mention between contemporary liberal democracies and ancient cultures. The penal code of the Old Testament, to give just one illustration, is likely to strike a modern person as an unspeakable mess of overcriminalization and overpunishment. Empirical studies have admittedly found a remarkable amount of agreement about matters of relative proportionality. People across different demographics and cultures tend to agree on quite nuanced seriousness rankings of 'core' crimes (Robinson 2013). ${ }^{15}$ But it is nevertheless striking that the penal policy of different countries is quite different in terms of absolute proportionality, and it is plausible to assume that this has some basis in different popular penal conventions (Robinson 2014). ${ }^{16}$

When faced with such variation, it may seem implausible to suggest that there is a universally true answer as to what offenders deserve. This seems to presuppose an ideal penal code governing any past, present, or future human society, and it is very difficult to believe that such a thing exists. Suppose future humans develop exoskeletons, making them impervious to physical assault. Such humans would presumably regard assault as much less wrongful than we do. Perhaps they would see punching someone as being rude, like bumping into someone. As a consequence of this, they would presumably also have a quite different idea about how to respond to assault. Examples like this seem to speak heavily in favor of popular retributivism. It would be odd to suggest that future people should adhere to our contemporary penal standards although their society is so different. ${ }^{17}$

But we must be careful here, because there is a subtle yet important distinction between desert claims being sensitive to changing contexts and the stronger claim that they are determined by popular conventions. It is quite plausible that the stuff that goes into proportionate punishments—criminal seriousness and penal severity-is sensitive to contextual (and variable) factors, but this doesn't mean that popular conventions determine proportionate punishments themselves. As I will argue in the next section, it is crucial that we distinguish between context sensitivity and convention sensitivity about desert. And I will suggest that we have no reason to endorse popular retributivism-a conventionsensitive view-just because we accept context sensitivity.

\footnotetext{
15 By 'core' crimes, Robinson (2013) means violent and property offenses as well as offenses that involve deceit in exchanges. He notes that there is much less agreement about how to rank crimes outside this core.

16 Although, as Robinson (2013, 128-140) also notes, the public tends to be more lenient than its state. Robinson suggests that this puzzle could be explained by ignorance: the public tends to express a desire for harsher sentences because it is unaware of the fact that actual penal policy already exceeds its standards of desert. This explanation does not invalidate the point that desert standards could vary between countries, however.

17 One reason not to hold different societies to our penal standards has to do with respect for democratic self-determination, the idea being that each society should get to decide which penal standards to adopt. Here, however, I am interested in the idea that the standards of desert change between different countries, which is a different matter.
} 


\section{Context Sensitivity and Convention Sensitivity}

Suppose a retributivist says 'crime $C$ deserves punishment $P$.' As noted in the previous section, evaluating this claim requires that we have values for $C$ and $P$, as well as some method of matching the two. But popular beliefs can operate on the claim in two quite different ways. On the one hand, they can determine, or otherwise inform, the values of $C$ and $P$. On the other hand, they can operate on the claim as such, that is, on the claim ' $C$ deserves $P$.' This is context sensitivity and convention sensitivity about desert, respectively:

Context sensitivity: Which punishment an offender deserves is sensitive to how harmful different crimes and punishments are, and this varies with context.

Convention sensitivity: Which punishment an offender deserves is determined by what is conventionally believed to be a deserved punishment.

Armed with this distinction, we can better assess the intuitive support for popular retributivism. Take again the example of future humans having developed exoskeletons. In such a world, it seems clear that assault is less deserving of punishment. But this is presumably so for the simple reason that the exoskeletons have made assault less harmful. There is nothing mysterious about saying that the wrongness of assault has to do with how harmful it is. Thus, the exoskeleton example doesn't prove the stronger point that popular conventions determine the deserved punishment itself. We may well want to say that, since assault is now such a minor harm, it would be disproportionate to ruin someone's life over it, and that state officials should disregard a convention among the public saying that those who commit assault should nevertheless be severely punished. But to say this is already to distance oneself from convention sensitivity.

We get a better grip of the distinction by looking at a recent paper by Matt Matravers (2014). In this paper, Matravers intends to challenge what he calls 'metaphysical' versions of retributivism, which he associates with philosophers like Kant, G.W.F. Hegel, and Michael Moore. Metaphysical versions of retributivism believe in a kind of desert that is freestanding from the social and political context. Matravers argues that this is wrongheaded, primarily on ontological grounds. ${ }^{18}$ Matravers contends that, rather than flowing from a 'celestial mechanics' connecting crimes with deserved punishments, judgments regarding what punishment a crime deserves are invariably formed by, and appropriate in, the particular context in which they are made. As he puts it, "judgments of seriousness and severity will reflect social conditions and practices such that what is deserved will be constituted by what is popularly believed to be-or what is implicit in current social practices as-serious, severe, and so proportionate' (ibid., 36-37).

Matravers offers England's infamous eighteenth century 'Bloody Code' as an illustration of his thesis. Most contemporary people will think that the Bloody Code produced an almost ludicrous amount of overpunishment, especially through its harsh treatment of property offenses. But Matravers warns against applying our own standards to a significantly different context. He suggests that the Bloody Code really did reflect the concerns of its time. It was a criminal law for the early stages of the industrial revolution, when masses

\footnotetext{
18 That Matravers' main complaint against metaphysical retributivism is ontological is evident from the fact that he rejects the idea of letting sentencing experts decide on the ground that there is no 'independent answer' as to what offenders deserve, and from the fact that he mentions Michael Moore's moral realism as a problem $(2014,35,43)$. But his criticism in other places relies on epistemic uncertainty and on political liberalism.
} 
of poor people poured into the cities in search of new lives. This created an unstable situation in which 'life was relatively plentiful and cheap' but 'establishing and securing property rights was essential' (ibid., 38). Thus, although few of the Bloody Code's many capital sentences were ultimately carried out, 'the seriousness of the code's protection of property and symbolic assertion of order are important components of understanding what was going on' (ibid., 38).

The Bloody Code example is meant to show that judgments of criminal seriousness are intimately woven up with the society in which punishment is practiced. Even if we agree that harm is key to criminal seriousness, Matravers argues, there is no context-independent vantage point from which to assess the rights and interests that go into defining harm. Instead, judgments of criminal seriousness 'reflect temporary agreement on contested rankings of what "really matters" in a human life' as well as the'socio-economic and cultural moment in which they are asked' more generally (ibid., 38-39). The Bloody Code treated the safeguarding of property as a much more urgent task than we are used to, but this was because doing so 'really mattered' in a rapidly industrializing society.

Just like judgments of criminal seriousness, judgments of penal severity are also tied up with the particular society in which punishment is practiced. Since the severity of punishment tracks how much a punishment typically sets back the interests of a person, social, political, and cultural agreements and expectations are once again central. ${ }^{19}$ As Matravers muses, to 'lose face in one culture may be much worse than to lose property in another' (ibid., 39). Such variations must be considered, he argues, because the state cannot hope to punish appropriately unless it tracks how different punishments are typically disvalued.

The upshot is that there is no answer regarding what punishment an offender deserves beyond what a society has agreed is a fitting response to his or her crime. Faced with true variation across different jurisdictions as to what offenders are thought to deserve, retributivists must say that the requirements of retributive justice differ correspondingly. As Matravers summarizes his thesis, "what is deserved for a given crime in Norway is very different from what is deserved for the same crime in the states of Georgia or Texas' (ibid., 41-42).

Matravers understands his argument as a defense of popular retributivism. ${ }^{20}$ More precisely, he wants to argue that someone who believes that that desert should govern how the state punishes lawbreakers must grant a central role to popular conventions. This much follows from his claim that 'desert is constituted by society's considered beliefs about what is deserved' $(2014,44)$. But his argument oscillates between context sensitivity and convention sensitivity and, while I think he wants to defend convention sensitivity, it is striking that most if not all of his examples draw on the weaker notion of context sensitivity.

Consider, for example, the argument that safeguarding property 'really mattered' during the social upheavals of the industrial revolution. This claim can be read as simply saying that theft was a greater wrong in eighteenth century England than it is in societies where property rights are more secure, just as physical assault is a greater wrong today than it would be in a future society in which people are shielded by exoskeletons. Nothing about

\footnotetext{
19 Another possibility here is that the severity of punishment is subjective in the sense that it tracks how bad it feels for the particular person undergoing it. Penologists usually want to avoid this view since it would expose retributivism to the unwelcome implication that tough-minded offenders should get more severe punishments than delicate ones (von Hirsch and Ashworth 2005, 147; see, however, Kolber 2009; Husak 2010, 433-449; Tonry 2011, 19-21).

20 Another possibility is that Matravers only wants to argue that criminal seriousness and penal severity are conventionally defined, which in turn affects proportionate punishment in a derivative way. But his claim that 'desert is constituted by society's considered beliefs about what is deserved' is pretty clearly an expression of convention sensitivity since it targets the deserved punishment itself.
} 
this example shows that popular conventions should determine how the state punishes theft or assault. It only shows that context-broadly understood to encompass societal norms and expectations-matters for how harmful crimes are. No version of retributivism, 'metaphysical' or otherwise, needs to deny this.

To give another and more realistic illustration of how criminal seriousness could be affected by context, consider that some societies are more honor-based than others (Pinker 2002, 326-329). It isn't unreasonable to think that defamation is more wrong in honorbased societies, again for the simple reason that it typically sets back the interests of the victim more. And, if this is true, any retributivist would have to say that defamation deserves a greater punishment in such societies. ${ }^{21}$

Similar things could be said about penal severity. Indeed, the case is arguably even more clear-cut here. Since punishment is about setting back the interest of the offender, it is essential to pay attention to the negative impacts of different treatments, and this is something that can change with context. The prison sentence, for example, relies on people typically valuing their freedom a great deal and on the fact that it is worse for people the longer they are deprived of their freedom. If people were to find time in prison as a welcome pause from their otherwise stressful lives, prisons would simply cease to be punishments.

The point is that context sensitivity is quite uncontroversial and unthreatening to retributivism in any guise. Indeed, when criminal seriousness and penal severity are affected by context, I would argue that context sensitivity is entailed by retributivism. It is a mistake to think that examples like the ones Matravers puts forward speak against objective retributivism. This view isn't tied to an unchanging theory of sentencing saying clearly absurd things like 'armed robbery has always deserved and will always deserve three years' imprisonment, no more and no less.' It can and should consider how harmful armed robbery and imprisonment is, and these are clearly things that can change with context. As it happens, even a 'metaphysical' retributivist like Kant seems to agree (Kant 1996, 107).

To qualify as popular retributivists, we would have to add that popular beliefs or conventions about deserved punishment matter. That is, popular beliefs matter not only for the values of $C$ and $P$ in the proposition ' $C$ deserves $P$ '; they also provide the test for the proposition as such. An objective retributivist could say something like 'In context $X$, punish $C$ by $P$ ' and by that have in mind an objective account of how crimes of a certain magnitude should be matched by punishments of a certain magnitude. For example, he or she might hold that the harms of $C$ and $P$ should be equivalent, or that the harm of $P$ should represent some fraction of the wrongful harm of $C$ (one half, one quarter, etc.). A popular retributivist, by contrast, rejects that any such account can be found. There are only beliefs about what kind of punishment different crimes deserve. If there is a true convention in a society that, for example, defaming the monarch can deserve 30 years' imprisonment, then this is indeed the deserved punishment in that society, irrespective of the values of this crime and this punishment. ${ }^{22}$

\footnotetext{
21 These remarks are about the harm component of criminal seriousness, but similar things could perhaps be said about the culpability component. Culpability is often taken to vary with (going from worst to least bad) intention, knowledge, recklessness, or negligence. It is conceivable that the order between these mental states could change with context, too. But I suspect that criminal law here follows moral common sense in a way that would make a different order unlikely. I will set this fascinating question aside here.

22 This was reportedly the punishment for defaming the recently deceased king of Thailand; see 'Man Jailed for 30 Years in Thailand for Insulting the Monarchy on Facebook,' The Guardian, 7 August, 2015. URL: https://www.theguardian.com/world/2015/aug/07/man-jailed-for-30-years-in-thailand-for-insulting-themonarchy-on-facebook.
} 
Is convention sensitivity plausible? Answering this question requires a meta-ethical discussion that lies beyond the scope of this paper. But there is no doubt that convention sensitivity turns retributivism into a far more unprincipled view than traditionally thought. Matravers exemplifies this problem by considering a hypothetical society in which homosexual acts are regarded as serious wrongs deserving of harsh punishments. He asks how popular retributivists could criticize this society. His answer is that they could criticize it for being inconsistent with its own values, or for violating human dignity, or for acting contrary to political liberalism. But if the society respects these constraints, popular retributivists couldn't (qua popular retributivists) condemn its practice of punishment (Matravers 2014, 46-48). ${ }^{23}$

For anyone who shares Matravers' discomfort about this result, but doesn't want to follow him in biting the bullet, the distinction I have drawn offers another way forward. It allows us to resist the claim that the community gets to decide what different offenders deserve even though we admit that popular beliefs are central to defining criminal seriousness and penal severity. Consider that a community may hold that criminal harm deserves to be met with twice the amount of penal harm, modified upwards or downwards by the offender's culpability. Mere context sensitivity doesn't commit us to respecting this popular standard: we could just as well argue that deserved punishment is when the penal harm is equal to, or a particular fraction of, the criminal harm. Not seeing the distinction between context sensitivity and convention sensitivity blinds us to this. The distinction also allows us to see what is going on when there are great differences in penal levels between jurisdictions, like between Sweden and Texas. It is fair to say that Sweden and Texas are not sufficiently dissimilar to justify the differences in penal levels. There is probably not a big difference between Sweden and Texas when it comes to, for example, how harmful an assault is for a typical person. The differences instead must have to do with the penal conventions. It seems to me that the Texan system is one according to which the penal harm should exceed the criminal harm, while the Swedish system may well have the opposite tendency. Context sensitivity does not force us to say that the requirements of retributive justice differ between Sweden and Texas; rather, it allows us to say that one or both jurisdictions are mistaken.

All I have said in this section is premised on that we should accept context sensitivity to begin with. Let me for the record say that I am not at all convinced that this is always correct. It might well be that we should be moral realists and say that people can be mistaken even about the way they understand criminal or penal harm. However, discussing this issue further would require a meta-ethical discussion that, again, I set to one side here.

While retributivists could resist convention sensitivity, it should be noted that is unclear whether specifically communicative versions of retributivism could do so. Communicative retributivists think that punishment is justified in virtue of conveying the community's censure of a criminal act. ${ }^{24}$ This idea gives penal conventions a robust standing, because punishment presumably won't communicate censure on behalf of a community unless it tracks the public's judgments of desert (how to pair crimes and

\footnotetext{
23 One might question whether Matravers' position is ultimately coherent on this point. If retributive justice is fundamentally convention sensitive, then why aren't the norms and values that constrain retributive justice (e.g., dignity) convention sensitive too? But, on a more charitable reading, Matravers' convention sensitivity is more like what Miller (2008) calls a 'meta principle.'

24 This glosses over important nuance and does not do justice to different examples of communicative retributivism, but I believe it captures the central claim of these theories.
} 
punishments). This is Matravers' main positive argument for popular retributivism, and I think he is right to point it out. But it should be noted that, even if the argument turns out to be sound, it wouldn't prove that retributivists should be popular retributivists. It could just as well be taken as a reason to reject communicative versions of retributivism.

\section{Penal Nudging}

I have argued that popular retributivism looks more plausible than it is because we fail to distinguish between context sensitivity and convention sensitivity. Having discussed the 'bad news' of this view-its unprincipled nature - let us now discuss the 'good news.' The good news is largely the flip side of the bad news. Since popular retributivism implies that any crime could in principle be proportionally punished by any punishment, it opens up the possibility of pursuing retributive justice in much less harmful ways. ${ }^{25}$

For a popular retributivist, it is important that the practice of punishment is in lockstep with the penal conventions of the community. The state may not reduce punishments if doing so brings it out of sync with the conventions. But there is no reason that popular retributivists would have to wait for the conventions to soften by themselves. They could also try to change the penal conventions by gently pushing them in a more lenient direction. Matravers notes this interesting aspect of popular retributivism. He writes that:

the community's beliefs about desert are not precise and allow for punishment within a range [...]. This offers the prospect of slowly ratcheting down sentencing levels by on each occasion choosing the lowest penalty within the range with the expectation that the new penalty will become the norm and a penalty slightly lower than that will then be included in the range in the future, and so on. (Matravers 2014, 45)

I will refer to this strategy as penal nudging. Penal nudging shares only a superficial resemblance with the concept of nudging in behavioral economics, where a 'nudge' refers to altering a person's behavior by non-coercively changing his or her choice architecture (Thaler and Sunstein 2008). But I find that the term captures the idea of gently pushing public penal opinion in a more lenient direction without forcing it down anyone's throat.

Penal nudging isn't a new idea. It resembles the 'decremental strategy' espoused by von Hirsch (1993, 36-46). But it has yet to receive sustained philosophical attention, and popular retributivism brings it into plain view. Objective retributivists cannot endorse penal nudging as in principle a good thing. They will say that the desirability of penal nudging depends entirely on whether the state is currently punishing too harshly. Popular retributivists, by contrast, are able to endorse penal nudging in general, precisely because they don't think that there is an 'external' standard of deserved punishment. When the popular standards are nudged in a more gentle direction, this doesn't compromise the state's ability to secure the good of retributive justice. It only means that securing retributive justice requires less penal harm, and probably also fewer economic resources.

There are two basic questions about penal nudging. First, could it succeed? Second, should it succeed? In what follows, I shall focus on the latter question. But let me first register a doubt about how far deserved punishments could be nudged in a more lenient direction.

25 There could of course be other reasons, such as the need for general deterrence or incapacitation, that speak against making punishment less harmful, but we are here focusing exclusively on retributivist reasons. 


\subsection{Could Penal Nudging Succeed?}

One doubt about the feasibility of penal nudging is that the public's beliefs about desert appear to be fairly rigid. Paul Robinson argues, on the back of a wealth of data, that people's intuitions of retributive justice are 'deeply embedded and not easily influenced' (Robinson 2013, 534). However, as Robinson also notes, these intuitions are mainly about relative blameworthiness, not absolute blameworthiness. Thus, penal nudging is a possibility, provided that it moves the whole set of punishments downwards. Robinson writes:

Because people do not have fixed intuitions about the general severity of punishment [...] reformers could over time shift a society's expectations towards lower severity. It would be a mistake to do so abruptly, for it might undercut moral credibility, but one could regularly reduce punishment levels across the board by an amount that would seem trivial in itself. For example, as an effort to reduce the overall cost of imprisonment on strained state budgets, one could reduce all sentences by 5 per cent, and could do so repeatedly over many years. (Robinson 2014, 69-70) ) $^{26}$

Let us grant that popular beliefs are malleable enough to permit this. There is a more conceptual reason to question the prospects for penal nudging. Consider that punishment can be broken down into two components: censure and hard treatment (von Hirsch and Ashworth 2005). Censure has to do with the amount of blame a punishment communicates. ${ }^{27}$ Hard treatment concerns what a punishment does in a more outward sense: in what ways does it deprive the offender of something he or she values, or infringes some of his or her rights? It seems that nudging the hard treatment component is much easier than the censure component. Consider the hypothetical case of the Lenient Society:

Lenient Society: Once upon a time there was a society that was very strict about law and order. People who broke the law were sent to prison for many years. The politicians thought the punishments far too draconian and decided to scale them down across the board. But, knowing full well that the legitimacy of the criminal justice system depends on the public accepting the punishments as retributively just, they did so gently. Each year they reduced the punishments slightly. For example, in the olden days murderers were sentenced to 50 years. This punishment was reduced by one year annually. Since people never thought there was a relevant difference between $k$ and $k-1$ years' imprisonment, and since the punishment for murder remained the most severe punishment, they never took issue with the changes. Forty nine years later, the punishment for murder was one year. Everyone thought this was what a murderer deserved, no more and no less. ${ }^{28}$

\footnotetext{
26 The reason Robinson says that punishments should be reduced 'across the board' is that reductions would otherwise clash with people's strong intuitions about relative blameworthiness. As noted in the introduction, Robinson argues that congruence between the criminal law and public opinion is important for ultimately consequentialist reasons.

27 This way of putting it is vague between what the state intends to communicate and what the offender experiences. Doug Husak, in personal correspondence, usefully suggests calling the former 'censure' and the latter 'stigma.'

${ }^{28}$ One reaction to this example is that it undermines the assumption of a singular deserved response for every crime. That the public is indifferent between 49 years and 50 years could mean that desert is 'disjunctive' (Hestevold 1983). But another response draws on epistemic uncertainty: perhaps there is at each point in time one singular answer as to how many years a murderer deserves but no reliable way of picking between $k$ and $k-1$ years (Duus-Otterström 2013). Morris' (1974) idea of 'limiting desert' could be interpreted along either of these lines.
} 
Did the punishment for murder become more lenient? In terms of hard treatment, the answer is clearly 'yes,' since the prison terms are shorter. But it isn't so obvious when it comes to censure. While hard treatment is a vehicle through which censure is communicated, it arguably isn't the absolute amount of hard treatment that expresses censure, but the relative amount. To see this, consider that 'the most severe punishment' doesn't have a fixed referent: it could refer to punishments of very different nature. And a punishment's censure is perhaps connected to where it sits in the set of all punishment rather than its absolute severity. It could be that murderers in the Lenient Society are censured just as much they used to be, simply because they suffer society's harshest punitive response.

The idea that the censuring element of punishment has to do with relative rather than absolute severity clashes with how some penologists think. In von Hirsch and Ashworth's influential analysis, censure is instead a function of hard treatment: the more hard treatment a punishment involves, the more that punishment is understood to express censure. Since this analysis holds that censure is for all intents and purposes inseparable from hard treatment, we may call it the 'inseparability account." 29 On this account, when the politicians of Lenient Society gradually reduced the amount of hard treatment, they also reduced the censure offenders were understood to experience. On the view I have suggested, this is not the case. We may say that this view presupposes a 'separability account': the degree to which a punishment is understood to censure is separate from the absolute amount of hard treatment it involves. The most plausible way to flesh out this account is that censure has to do with the relative severity of hard treatment. ${ }^{30}$

Which of the two accounts is true is an empirical question, and I am unaware of any study that could help us choose between them. But seeing the difference between them is important for the normative question of whether successful penal nudging would be a good thing. As I will argue in the next section, penal nudging seems desirable if, as the separability account admits, it does not affect the levels of censure. Whether it would be desirable on the inseparability account is less clear.

\footnotetext{
${ }^{29}$ von Hirsch and Ashworth argue that hard treatment serves two functions: it credibly expresses censure and it provides prudential disincentives. Although this gives hard treatment a robust standing in their account, they also entertain the thought that the appropriate degree of censure could be expressed in merely 'symbolic' ways (e.g., a public denouncement). This makes clear that censure is not a constitutive part of punishment on their account; 'punishment' is rather the same thing as hard treatment (von Hirsch and Ashworth 2005, Ch. 2). I think it is a mistake to conflate punishment and hard treatment in this way. Generically understood, punishment consists in setting back the interests of an offender. Since to be censured is typically a setback to one's interests, it follows that the degree to which one experiences censure is relevant for how much one is punished, at least if this setback is intended as opposed to merely foreseen (Boonin 2008, 179). We see this particularly clearly if we imagine that the severity of a punishment could be mapped onto a scale of hedonic wellbeing. Since censure and hard treatment are both sources of displeasure, the effects of a punishment for someone's placement on that scale would be a function of both the amount of hard treatment and the amount of censure. For a defense of separating censure and hard treatment, see Husak (2010, 433-449) and Scanlon (2013).

${ }^{30}$ Husak (2010, 433-449) also argues that censure (or 'stigma') contributes independently to the overall severity of punishment. Proportionality in punishment may therefore require less hard treatment when offenders have suffered or will suffer a lot of censure. For example, public figures who have been vilified in the press may be entitled to less hard treatment, in order not to be punished more harshly than they deserve. Husak's discussion assumes, controversially, that being vilified in the press should count towards a person's punishment and not merely towards the negative impacts that are inflicted on someone for having committed a crime. We need not accept this assumption to accept that censure can contribute independently to the severity of a punishment.
} 


\subsection{Should Penal Nudging Succeed?}

The most morally problematic part about punishment is hard treatment. It is primarily hard treatment that disrupts relationships, ruins careers, and puts a significant strain of the public coffers. It is much less pressing - if desirable at all-to reduce how much offenders are censured for their crimes. Indeed, the displeasure produced by censure is usually thought of as the core retributive good. Even critics of retributivism agree that 'the idea that it is good that wrongdoers suffer emotionally is the most intuitively attractive claim that retributivists make' (Tadros 2011, 45). ${ }^{31}$ On the separability account, however, we shouldn't worry too much about penal nudging undermining this good since the degree of censure is independent of the absolute amount of hard treatment. And, under such conditions, penal nudging would presumably be a good thing. We would get the same amount of what seems central to retributive justice - censure-while inflicting less hard treatment. ${ }^{32}$

On the inseparability account, it is much less clear whether retributivists should endorse penal nudging. Since this account holds that amount of censure is a function of the amount of hard treatment, reducing the amount of hard treatment means less censure. Would this be a good thing according to a retributivist? It is tempting to answer 'no,' precisely because the pain caused by censure is a core retributive good. If people are censured less in the future, and as a result experience less guilt, then it appears we have lost something of value as far as retributivists are concerned. Put simply, there would be less deserved blame.

But note that this response once again brings the difference between objective retributivism and popular retributivism into focus, as it assumes that there is a correct standard as to how much blame an offender really deserves (or at least a sense in which an offender could be blamed too little). Popular retributivists would deny this, and so they would see nothing in itself problematic about levels of censure coming down. To illustrate, suppose the politicians of Lenient Society are able to soften the public's beliefs about how much censure murderers deserve. Yet, even though this means that murderers will be less censured, people ex hypothesi would still think of the amount of censure directed towards murderers as the amount murderers deserve, no more and no less, so it isn't clear what would be lost as far as the popular retributivists are concerned. What is lost can't be the blame that murderers really deserve because popular retributivists deny that there is a vantage point from which to assess the correct level of blame beyond the popular conventions. $^{33}$

It isn't only convention sensitivity that raises difficult questions here. Context sensitivity, too, seems counterintuitive in light of penal nudging. Context sensitivity means that criminal seriousness and penal severity are affected by changing social, cultural, and

\footnotetext{
31 Tadros (2011) argues that while that it is good that offenders recognize that what they did was wrong it is not intrinsically good that they feel bad about it. For critical discussion, see Husak (2013).

32 Some argue that punishment (especially imprisonment) is justified in part because it provides a setting for offenders to confront uncomfortable questions about themselves. Most famously, Duff (2001) argues that prison is a context for 'secular penance.' On the secular penance view there are probably limits to how far penal nudging should go. Prison terms should not be so short as to undermine self-reflection and potential moral reform.

33 A possible rejoinder on behalf of popular retributivism is that what is lost is not so much censure of the offender as it is condemnation of the crime. Thus, the problem with penal nudging is that it risks trivializing crime, either in an empirical sense (if people start to censure murderers less, they will also tend to condemn murder less) or in a conceptual sense (the degree to which a society censures people who commit crimes $i s$ the same thing as the degree to which it condemns those crimes). But popular retributivists can't appeal to this rejoinder, because it presupposes an objective standard as to how far different crimes should be condemned.
} 
political circumstances. For example, as I suggested above, a crime like defamation is only wrongful provided that people typically think that having one's character attacked in public is a setback to one's interests. If punishments for defamation were decrementally reduced, bringing the censure of defamation with them, wouldn't this mean precisely that people thought less of being defamed? And from what position could that development then be condemned?

There is, however, an important difference between context-sensitive and conventionsensitive retributivism. Unlike the latter, the former is fully compatible with an objective approach to sentencing. Context-sensitive retributivism merely says that, if a harm of a certain magnitude is inflicted, then a punishment of a certain magnitude is deserved. This is compatible with taking a normative approach to the context itself. For example, it is perfectly coherent for context-sensitive retributivists to hold that defamation ought to be regarded as a serious setback to one's interest. If this is held, and if it is known that penal nudging will eventually affect how people typically regard defamation, then this provides a reason not to nudge punishments for defamation. Recall that we are now assuming that the inseparability account is correct, meaning that censure is a function of hard treatment. The point is that, if we can foresee that reducing hard treatment would trivialize crime, retributivists may conclude that reducing hard treatment is undesirable, and nothing about context sensitivity contradicts that conclusion.

This line seems to me intuitively appealing. After all, it is conceivable that public beliefs and values change considerably over time. Even without manipulation or other kinds of nefarious influence, the public may come to treat crimes we currently regard as serious as quite minor. But, although such changes arguably affect how punishment should be meted out once they have occurred-if a crime has become less harmful in virtue of being considered less of a setback to the victim, then a retributivist must conclude that it merits less punishment-it isn't strange that one would want to resist that development $e x$ ante. The fact that some crimes ought to be regarded as serious gives us a reason to make sure that they aren't regarded as minor in the future, and this in turn could give us a reason to refrain from penal nudging (and a reason to regret penal nudging if it were to succeed). Popular retributivists cannot accept any of this since they reject the idea that a crime ought to be censured more/less than the public finds appropriate, at least when the public has considered beliefs about it. Whether they are right in doing so is a question I won't try to answer. Still, at the level of intuition, most of us have no problem imagining that society might adopt bad values in the future, including values that pertain to punishment and retributive justice. If penal nudging would lead society into making such moral mistakes, it isn't strange that a retributivist would want to resist it ex ante, and it counts in favor of context-sensitive retributivism that it is compatible with that intuition.

This also has implications for a topic I have skirted around in this paper: criminalization. Retributivists hold that only appropriately criminalized actions deserve punishment. But are there external constraints as to which actions may be criminalized or could any action in principle come within the purview of the criminal law? Conventionsensitive retributivists would struggle to put any external constraints on the criminal law. Context-sensitive retributivists, however, would not, precisely because they can take a normative approach to the context in which punishment is practiced. True, if actions we currently take to be minor wrongs were to become regarded as serious public wrongs, this would permit criminalizing them according to context-sensitive retributivism. But context-sensitive retributivism need not take an ex post perspective. It can say that, while minor wrongs could permissibly be criminalized given certain societal or cultural 
changes, this would be a development for the worse, and one whose preconditions should be resisted. ${ }^{34}$

\section{Conclusion}

It fairly common to argue that congruence between penal policy and public opinion is important for consequentialist reasons, but not much has been written about whether it could also be important according to retributivism. I have argued that there are ways of making retributivism sensitive to public opinion or public conventions without arriving at the conclusion that popular conventions should govern retributive justice itself. I have suggested that retributivists can be context sensitive while taking an objective approach to desert. Moreover, they can take a normative approach to the context in which punishment is to be practiced, refraining from ushering in changes that would mean that serious crimes are regarded as more minor. It is my hope that this paper will encourage political and legal philosophers to think more about the relationship between public opinion and retributivism as well as about the constituent parts of deserved punishment more generally. We know less about these important questions than we should.

Acknowledgements Previous versions of this paper were presented at the Association of Social and Political Philosophy, Amsterdam, and at the University of Oslo, both in 2015. I am grateful for all the advice and comments I received on those occasions, especially from Kim Angell, Christopher Bennett, Albert Dzur, Robert Huseby, Annabelle Lever, and Bill Wringe. Special thanks goes to Andrei Poama, who organized the workshop on popular punishment in Amsterdam, and Jakob Elster, who provided superb written comments on an earlier draft, alerting me to what later became the distinction between context and convention sensitivity. The research is part of the project Fair-Play Retributivism and the Problem of Punishment, funded by the Swedish Research Council (Grant Number 2011-1559).

Open Access This article is distributed under the terms of the Creative Commons Attribution 4.0 International License (http://creativecommons.org/licenses/by/4.0/), which permits unrestricted use, distribution, and reproduction in any medium, provided you give appropriate credit to the original author(s) and the source, provide a link to the Creative Commons license, and indicate if changes were made.

\section{References}

Andeweg, Rudy. (2011). 'Approaching Perfect Policy Congruence: Measurement, Development, and Relevance for Political Representation.' In Martin Rosema, Bas Denters and Kees Aarts (eds.), How Democracy Works. Amsterdam: Amsterdam University Press, 39-52.

Bennett, Cristopher. (2008). The Apology Ritual. Cambridge: Cambridge University Press.

Bennett, Christopher. (2014). 'Public Opinion and Democratic Control of Sentencing Policy.' In Jesper Ryberg and Julian Roberts (eds.), Popular Punishment. Oxford: Oxford University Press, 146-162.

Bird, Colin. (2006). An Introduction to Political Philosophy. Cambridge: Cambridge University Press.

Boonin, David. (2008). The Problem of Punishment. Cambridge: Cambridge University Press.

Brooks, Thom. (2012). Punishment. London: Routledge.

Davis, Michael. (1983). 'How to Make Punishment Fit the Crime.' Ethics 93(4): 726-752.

Duff, Antony. (2001). Punishment, Communication, and Community. Oxford: Oxford University Press.

Duus-Otterström, Göran. (2013). 'Why Retributivists Should Endorse Leniency in Punishment.' Law \& Philosophy 32(4): 459-483.

Dzur, Albert. (2012). Punishment, Participatory Democracy, and the Jury. New York: Oxford University Press.

\footnotetext{
${ }^{34}$ This is obviously just a sketch of an answer. For insightful discussion about the limits of criminal law, see Tomlin (2013).
} 
Gilens, Martin. (2012). Affluence \& Influence: Economic Inequality and Political Power in America. Princeton: Princeton University Press.

Hestevold, Scott. (1983). 'Disjunctive Desert.' American Philosophical Quarterly 20(4): 357-363.

Hoskins, Zachary. (2016). 'Punishment.' Analysis, online first.

Husak, Douglas (2010) The Philosophy of Criminal Law. Oxford: Oxford University Press.

Husak, Douglas. (2013). 'Retributivism in Extremis.' Law and Philosophy 32(1): 3-31.

Kagan, Shelly. (2012). The Geometry of Desert. Oxford: Oxford University Press.

Kant, Immanuel. (1996). The Metaphysics of Morals. Mary Gregor, trans. Cambridge: Cambridge University Press.

Kolber, Adam. (2009). 'The Subjective Experience of Punishment.' Columbia Law Review 109: 182-236.

Kuklinksi, James, and Buddy Peyton. (2007). 'Belief Systems and Political Decision Making.' In Russell Dalton and Hans-Dieter Klingemann (eds.), Oxford Handbook of Political Behavior. Oxford: Oxford University Press, 45-64.

Lippke, Richard. (2014). 'Some Surprising Implications of Negative Retributivism.' Journal of Applied Philosophy 31(1): 49-62.

Matravers, Matt. (2014). 'Proportionality Theory and Public Opinion.' In Jesper Ryberg and Julian Roberts (eds.), Popular Punishment. Oxford: Oxford University Press, 33-53.

Miller, David. (2008). 'Political Philosophy for Earthlings.' In David Leopold and Marc Stears (eds.), Political Theory: Methods and Approaches. Oxford: Oxford University Press, 29-48.

Morris, Norval. (1974). The Future of Imprisonment. Chicago: The University of Chicago Press.

Pinker, Stephen. (2002). The Blank Slate. New York: Viking.

Rachels, James. (1997). 'Punishment and Desert.' In Hugh LaFollette (ed.), Ethics in Practice. Oxford: Blackwell, 470-479.

Robinson, Paul. (2013). Intuitions of Justice and the Utility of Desert. Oxford: Oxford University Press.

Robinson, Paul. (2014). 'The Proper Role of Community in Determining Criminal Liability and Punishment.' In Jesper Ryberg and Julian Roberts (eds.), Popular Punishment. Oxford: Oxford University Press, 54-75.

Ryberg, Jesper, and Julian Roberts (eds.) (2014). Popular Punishment. Oxford: Oxford University Press.

Scanlon, T.M. (2013). 'Giving Desert its Due.' Philosophical Explorations 16(2): 101-116.

Stimson, James, Michael Mackuen, and Robert Erikson. (1995). 'Dynamic Representation.' American Political Science Review 89(3): 543-565.

Tadros, Victor. (2011). The Ends of Harm. Oxford: Oxford University Press.

Thaler, Richard, and Cass Sunstein. (2008). Nudge: Improving Decisions about Health, Wealth, and Happiness. New Haven: Yale University Press.

Tomlin, Patrick. (2013). 'Extending the Golden Thread? Criminalisation and the Presumption of Innocence.' The Journal of Political Philosophy 21(1): 44-66.

Tomlin, Patrick. (2014). 'Retributivists! The Harm Principle Isn't for You!' Ethics 124(2): 272-298.

Tonry, Michael. (2011). 'Can Twenty-first Punishment Practice Be Justified in Principle?' In Michael Tonry (ed.), Retributivism Has a Past. Has it a Future? Oxford: Oxford University Press, 3-29.

von Hirsch, Andrew. (1993). Censure and Sanctions. Oxford: Oxford University Press.

von Hirsch, Andrew, and Andrew Ashworth. (2005). Proportionate Sentencing: Exploring the Principles. Oxford: Oxford University Press.

Walzer, Michael. (1987). Interpretation and Social Criticism. Cambridge, MA: Harvard University Press.

Wlezien, Christopher. (1995). 'The Public as Thermostat: Dynamics of Preferences for Spending.' American Political Science Review 39(4): 981-1000.

Zaller, John. (1992). The Nature and Origins of Mass Opinion. Cambridge: Cambridge University Press. 